\title{
The Perception of Residents of Makurdi, Benue State, Nigeria about the Veterinary Profession
}

\author{
Samuel A. Ode ${ }^{1}$, Ugoh Nsoffor ${ }^{1}$, James S. Gberindyer ${ }^{1}$, \\ Emmanuella N. Akange-Ejeye ${ }^{1}$, Innocent I. Luga ${ }^{2}$ and Nicodemus M. Useh ${ }^{1^{*}}$ \\ ${ }^{1}$ Department of Veterinary Pathology and Microbiology, College of Veterinary Medicine, University of \\ Agriculture, Makurdi, Nigeria. \\ ${ }^{2}$ Department of Veterinary Public Health and Preventive Medicine, University of Agriculture, \\ Makurdi, Nigeria.
}

\section{Authors' contributions}

This work was carried out in collaboration among all authors. Author NMU designed the study, wrote the protocol, interpreted the data and prepared the manuscript. Authors SAO, UN and IIL anchored the field study, gathered the initial data and performed preliminary data analysis, while authors JSG, UN and ENA-E managed the literature searches and produced the initial draft. All authors read and approved the final manuscript

Article Information

DOI: 10.9734/ARRB/2019/v31i230044 Editor(s):

(1) Dr. George Perry, Dean and Professor of Biology, University of Texas at San Antonio, USA. Reviewers:

(1) Otolorin, Gbeminiyi Richard, Ahmadu Bello University, Zaria, Nigeria. (2) M. Zamri Saad, Universiti Putra Malaysia, Malaysia. Complete Peer review History: http://www.sdiarticle3.com/review-history/22151

Original Research Article

Received 04 August 2015

Accepted 27 October 2015

Published 25 March 2019

\begin{abstract}
Veterinary medicine is the medical science that is concerned with the diagnosis, treatment, prevention and control of diseases, disorders and injuries of animals. A questionnaire-based study was conducted to investigate the perception of Nigerians resident in Makurdi city about the veterinary profession. Makurdi city, located in Central Nigeria, was divided into 10 sub-study areas for the purpose of the survey. Exactly 965 questionnaires were administered randomly to respondents in the study areas and collected immediately they were completed. Data obtained from the study was collated and analyzed using Chi square (statistical package for social sciences, SPSS) and values of $\mathrm{P}<0.05$ were significant. Majority of the respondents ( $\mathrm{n}=936$ or $96.99 \%$ ) confirmed they had prior knowledge about the identity of a veterinary doctor before the study. Most respondents $(\mathrm{P}<0.05)$ strongly agreed that veterinary doctors usually receive more standard
\end{abstract}

*Corresponding author: E-mail: nicodemus.useh@fulbrightmail.org; 
professional training than animal scientists. Half of the respondents $(n=485$ or $50.2 \%)(P<0.05)$ strongly agreed that veterinary and human medicine are complimentary in the disease control strategy plan of any nation. Majority of the respondents $(P<0.05)$ either strongly agreed or agreed that ranches should be established for rearing livestock in Nigeria to prevent frequent farmerherdsmen clashes that have been on the increase in recent times. The significance of these findings and the implication on the development of the livestock industry in Nigeria are discussed.

Keywords: Perception; Residents of Makurdi; Benue State; Nigeria; veterinary profession.

\section{INTRODUCTION}

Veterinary medicine is the medical science that is concerned with the diagnosis, treatment, prevention and control of diseases, disorders and injuries of animals. Veterinarians prevent the transmission of animal diseases to human beings and advice pet owners on the proper care of animals. They also work to ensure safe food supply by maintaining the health of animals, and by inspecting food processing industries. Veterinarians are also involved in the preservation of wildlife [1].

Veterinary medicine is that branch of science restricted by law to be practiced only by registered veterinary surgeons or veterinary doctors [2]. The Veterinary Surgeon's Act Nigeria (1969) amended by Act No. 40, 1987 of the Federal Republic of Nigeria defines a veterinary doctor as a person who has satisfied the legal requirements for registration as a veterinary surgeon (as stated in section 8 , subsections 1 and 2 of the Veterinary Surgeon's Act) and has been duly registered by the Veterinary Council of Nigeria (VCN) as empowered by section 5 , subsection 3 of the Act [3].

The modern veterinary profession began in 1762 in Lyon, France with the establishment of the first veterinary college in history [4]. The college was established to provide scientific and professional training for comparative medicine, as it was believed that medicine is one (human and animal), but veterinary medicine was comparative, more comprehensive and more demanding in terms of efforts and resources [3]. In Nigeria, veterinary medicine started with the establishment of the Veterinary Department in 1914 and the recruitment of G. E. Owen and F. $R$. Brandt as pioneer veterinary officers [5]. The mandate of the Department included the promotion of animal health and the practice of systematic animal husbandry for the production of food of animal origin, especially meat, milk and other dairy products for human consumption [3]. Since the 1960s, veterinary colleges have been established in various universities in Nigeria, with 8 having been accredited as at 2006 [4]. A previous study showed low public awareness about the veterinary profession in Nigeria (Adewumi and Ebotmanchang, 2004). In the present study, we report for the first time, the perception of residents of Makurdi city in Central Nigeria about the veterinary profession.

\section{MATERIALS AND METHODS}

\subsection{Study Location}

The study was carried out in Makurdi, the capital city of the food basket state (Benue), Nigeria. Makurdi is located on Latitude $7.74^{\circ} \mathrm{N}$ and Longitude $8.51^{\circ} \mathrm{E}$. The city has a population of 300,337 persons [6].

\subsection{Experimental Procedure}

For the convenience of sampling, Makurdi town was split into 10 sub-study areas namely; University of Agriculture Community, North-Bank, Wurukum, High level, Benue State University Community, Judges Quarters, Nyiman Layout, New GRA, Low Level and Industrial Layout for the study. A total of 965 questionnaires were randomly administered to residents of the 10 sub-study locations and respondents were required to answer the questions and return them immediately. The questionnaires consisted of 2 sections (A and B). Section A contained a question that required information about the respondent's personal profile. The question was related to the employment status of the respondent, for which s/he was required to state whether s/he was a student, employed or unemployed. There was no requirement for age, sex, tribe or religion, as these were not relevant for the study. Section B contained questions that were intended to assess the respondent's knowledge about the veterinary profession and its role in the society. It comprised a question that required a "yes" or "no" answer followed by subsequent questions that required answers 
such as "strongly agree, agree, strongly disagree, disagree or no idea" respectively.

\subsection{Statistical Analysis}

The questionnaires were collated and sorted according to the various sub-study areas, pooled together and the data obtained from each, including the cumulative data was compiled in tabular form. The data was analyzed using Chi square (SPSS) and values of $\mathrm{P}<0.05$ were significant [7].

\section{RESULTS}

A total of $435(45.1 \%)$ respondents were students while $364(37.7 \%)$ were employed and $166(17.2 \%)$ were unemployed. Majority of them $(n=936$ or $96.99 \%)$ confirmed that they heard about a veterinary doctor before the study. Only $29(3 \%)$, comprising $5(0.52 \%)$ students, 1 $(0.1 \%)$ employed and $23(2.38 \%)$ unemployed respondents never heard of a veterinary doctor prior to the study. Most respondents $(n=741$ or $76.8 \%$ ) strongly agreed that a veterinary doctor is a professional who is authorized by law to diagnose and treat animal diseases. $A$ substantial number of them ( $n=343$ or $35.6 \%$ ) strongly agreed, and another number in the same neighbourhood $(n=333$ or $34.5 \%)$ agreed that veterinary doctors usually receive a more standard training on livestock management, production and health compared to animal scientists. Only a few respondents $(n=65$ or $6.7 \%$ ) strongly disagreed. This showed a statistically significant difference $\quad(P<0.05)$ between the former and the later. Half of the respondents ( $n=485$ or $50.2 \%$ ) strongly agreed that veterinary and human medicine are complimentary in the disease control strategy plan of any nation (Table 1). A slightly lower number of respondents strongly agreed $(n=303$ or $31.4 \%)$ than agreed $(n=309$ or $32 \%)$ that Nigerian abattoirs are in their current state of dilapidation because veterinarians have not been authorized by law to manage them.

More than half of the respondents $(n=575$ or $59.6 \%$ ) strongly agreed that for effective disease diagnosis, treatment, prevention and control, Veterinary Teaching Hospitals (VTHs) in Nigerian universities should be equipped and better funded than it currently obtained. Most respondents ( $n=537$ or $55.7 \%$ ) strongly agreed that household animal production for family income generation in Benue state has not been encouraged by government through provision of essential support facilities to peasant farmers. More respondents ( $\mathrm{n}=357$ or $37.0 \%$ ) strongly agreed than agreed ( $n=257$ or $26.6 \%$ ) that to reduce farmer-transhumance nomadic Fulani clash, the Fulani herdsmen should be encouraged to settle and establish ranches for effective livestock business in Nigeria compared to $110(n=11.4 \%)$ that strongly disagreed. Majority of the respondents ( $n=650$ or $67.4 \%$ ) strongly agreed, while 251 (26.0\%) agreed that Nigerian government at the state and federal levels should establish treaties and cooperation agreements with the governments of developed nations to train its veterinarians. Most respondents ( $n=764$ or $79.2 \%$ ) strongly agreed and others $(n=143$ or $14.8 \%)$ agreed that Nigerian government should encourage veterinarians to be self employed after graduation from the universities by providing them interest-free loan facilities to establish livestock farms, veterinary clinics or other professional transactions to reduce the country's unemployment burden (Table 1). Results of findings from the individual sub-study locations in Makurdi town were also in tandem with the cumulative result (Table 1 ) and are presented in Tables 2-11.

\section{DISCUSSION}

The veterinary profession in Nigeria is relatively young compared to that in developed countries such as the United States of America, Great Britain, Germany or Canada. For a very long time there was the problem of lack of awareness about the veterinary profession in Nigeria. About a decade ago, Adewumi and Ebotmanchang [8] reported low awareness level about the veterinary profession among some categories of Nigerians. It is gratifying to note that in the present study, $96.99 \%$ of Nigerians resident in Makurdi city were reported to be aware about the existence and duties of a veterinary doctor. It is not impossible that some respondents in the study may have actually patronized the services of veterinarians at some point in Benue state or other parts of Nigeria. The high level of awareness about the veterinary profession observed in the present study may be attributed to 1) the high literacy level in Makurdi, evidenced by the presence of 2 universities within the city. The presence of other tertiary institutions in Makurdi further support our suspicion that the high literacy level may be one factor responsible for the high level of awareness observed in the study. It is also not unlikely that the awareness level about the veterinary profession in other 
parts of Benue state may not be as high or even low because of the increased level of illiteracy in the villages. 2). The Veterinary Teaching Hospital and the College of Veterinary Medicine of the University of Agriculture, Makurdi, Nigeria as well as the state veterinary clinic are all located within Makurdi metropolis and their activities may have created significant awareness about the veterinary profession. All these taken together may be good reasons why the awareness level about the veterinary profession was very high in Makurdi, Nigeria.

The finding that veterinary doctors usually receive a more standard training on livestock management, production and health compared to animal scientists should excite every veterinarian in Nigeria that the Nigerian society is already becoming better informed on a daily basis that veterinarians are key players in the livestock industry by virtue of their training, which combines both livestock management and health, contrary to animal scientists that are only trained on livestock management and general production, without most aspects of animal health.

One interesting finding in the study is that respondents were not only aware that household livestock production is an important aspect of revenue generation for the family, but that the Nigerian government has not done much to provide support for peasant farmers in this area. It is well known that poverty can be best alleviated at the level of the nuclear family if the country's quest to eradicate poverty and malnutrition through vision $20-20-20$ is to be realized. The opinion of majority of Makurdi residents $(P<0.05)$ was that nomadic pastoralism through transhumance should be replaced by the establishment of ranches, which have a more comparative advantage. It is known that ranches are more likely to produce animals with higher weight gains than transhumance. Net annual body weight gain of African zebu cattle is usually around $50 \mathrm{~kg}$, so that mature size is reached only at 5-6 years of age [9]. This is in addition to the twin advantages of eradicating violent clashes between farmers and nomads and the possibility of ranches to be a source of job creation for unemployed Nigerians.
The study identified the expertise of the Nigerian veterinarian and his ability to turn situations around, as most respondents strongly agreed $(P<0.05)$ and others further agreed $(P<0.05)$ that Nigerian abattoirs are in their current state of disrepair because veterinarians have not been authorized by law to manage them. This in the view of the authors is great feat for the veterinary profession in Nigeria. Based on this finding, it was speculated that most elites in the Nigerian society are aware, without any doubts, about the problem solving capabilities of the veterinarian. This statement becomes even more patronizing if placed side by side with the finding in the present study that majority of respondents $(P<0.05)$ strongly agreed and others further agreed $(P<0.05)$ that veterinary and human medicine are complimentary in the disease control strategy plan of any nation. Only a negligible number of respondents $(P>0.05)$ strongly disagreed. With the advent of one medicine [10], the whole world has swallowed pride and accepted that medicine is one. The foregoing report shows that Nigerian elites are aware about the global strategies for health promotion.

For about 2 decades, the training of veterinarians in Nigeria has been marred by dilapidated infrastructure in the universities and the dearth of qualified academics. It appears that Nigerian elites resident in Makurdi are aware of this as most respondents $(P<0.05)$ strongly agreed that Nigerian government at the state and federal levels should establish treaties with the governments of developed nations to assist in the training of veterinarians. Veterinarians are a group of cosmopolitan professionals, whose training qualifies them to fit in research, science, industry, banking and finance, diplomacy, academia and space, even much more than conventional professionals in these endeavours. It is evident that the intellectual content of the veterinary training at Nigerian universities has continued to dwindle over time, with no much effort to reverse the trend. The suggestion in this study that foreign training of Nigerian veterinarians through treaties with renowned veterinary colleges overseas will reverse the dwindling fortunes of veterinary colleges in Nigeria should be critically evaluated by policy makers for effective design and implementation. 
Table 1. Result of cumulative data obtained from the study

\begin{tabular}{|c|c|c|c|c|c|c|}
\hline \multicolumn{7}{|c|}{ Cumulative data obtained } \\
\hline Students: 435 (45.1\%) & \multirow{3}{*}{$\begin{array}{l}\text { Employed: } 364(37.7 \%) \\
\text { Employed who have not } \\
\text { heard of vet: } 1\end{array}$} & \multicolumn{3}{|c|}{ Unemployed: 166 (17.2\%) } & \multicolumn{2}{|c|}{ Total: 965 (100\%) } \\
\hline \multirow{2}{*}{$\begin{array}{l}\text { Students who have not heard } \\
\text { of vet: } 5 \\
\text { Questions }\end{array}$} & & \multicolumn{3}{|c|}{ Unemployed who have not heard of vet: 23} & \multicolumn{2}{|c|}{ Total: $29(3 \%)$} \\
\hline & & Strongly agree & Agree & Strongly disagree & Disagree & No idea \\
\hline \multicolumn{2}{|c|}{$\begin{array}{l}\text { A veterinary doctor is a professional who is licensed to diagnose } \\
\text { and treat animal diseases }\end{array}$} & $741(76.8 \%)$ & $181(18.8 \%)$ & $1(0.1 \%)$ & $3(0.3 \%)$ & $39(4.0 \%)$ \\
\hline \multicolumn{2}{|c|}{$\begin{array}{l}\text { A veterinary doctor is a laboratory scientist that diagnoses and } \\
\text { treats animal diseases }\end{array}$} & $412(42.7 \%)$ & $369(38.2 \%)$ & $52(5.4 \%)$ & $56(5.8 \%)$ & $76(7.9 \%)$ \\
\hline \multicolumn{2}{|c|}{ A veterinary doctor is a community leader in the scientific world } & $282(29.2 \%)$ & $227(23.5 \%)$ & $156(16.2 \%)$ & $166(17.2 \%)$ & $134(13.9 \%)$ \\
\hline \multicolumn{2}{|c|}{$\begin{array}{l}\text { Veterinary doctors have a more standard training programme on } \\
\text { livestock management, production and health; compared to animal } \\
\text { scientists }\end{array}$} & $343(35.6 \%)$ & $333(34.5 \%)$ & $65(6.7 \%)$ & $82(8.5 \%)$ & $142(14.7 \%)$ \\
\hline \multicolumn{2}{|c|}{$\begin{array}{l}\text { Nigerian abattoirs are in a bad state because veterinarians have } \\
\text { not been authorized by law to manage them }\end{array}$} & $303(31.4 \%)$ & $309(32.0 \%)$ & $55(5.7 \%)$ & $106(11.0 \%)$ & $192(19.9 \%)$ \\
\hline \multicolumn{2}{|c|}{$\begin{array}{l}\text { Veterinary medicine and human medicine are complementary in } \\
\text { the disease control strategy of any nation }\end{array}$} & $485(50.2 \%)$ & $338(35.0 \%)$ & $16(1.7 \%)$ & $22(2.3 \%)$ & $104(10.8 \%)$ \\
\hline \multicolumn{2}{|c|}{$\begin{array}{l}\text { For effective disease diagnoses, prevention and control, veterinary } \\
\text { teaching hospitals in Nigerian universities should be equipped and } \\
\text { better funded than it is currently }\end{array}$} & $575(59.6 \%)$ & $298(30.9 \%)$ & $13(1.3 \%)$ & $9(0.9 \%)$ & $70(7.3 \%)$ \\
\hline \multicolumn{2}{|c|}{$\begin{array}{l}\text { Household animal production for family income generation in } \\
\text { Benue state has not been encouraged by the government via } \\
\text { provision of essential support facilities to the farmer }\end{array}$} & $537(55.7 \%)$ & $274(28.4 \%)$ & $12(1.2 \%)$ & $29(3.0 \%)$ & $113(11.7 \%)$ \\
\hline \multicolumn{2}{|c|}{$\begin{array}{l}\text { To reduce farmer-transhumance nomadic Fulani clash, the Fulani's } \\
\text { should be encouraged to settle and establish ranches for effective } \\
\text { livestock business in Nigeria }\end{array}$} & $357(37.0 \%)$ & $257(26.6)$ & $110(11.4 \%)$ & $163(16.9 \%)$ & $78(8.1 \%)$ \\
\hline \multicolumn{2}{|c|}{$\begin{array}{l}\text { Nigerian governments should establish treaties with the } \\
\text { governments of developed countries to train its veterinarians both } \\
\text { locally and internationally }\end{array}$} & $650(67.4 \%)$ & $251(26.0 \%)$ & $13(1.3 \%)$ & $9(0.9 \%)$ & $42(4.4 \%)$ \\
\hline \multicolumn{2}{|c|}{$\begin{array}{l}\text { Nigerian government should encourage veterinarians to be self } \\
\text { employed after graduation from the university by providing them an } \\
\text { interest free loan to establish livestock farms, veterinary clinics or } \\
\text { other professional businesses }\end{array}$} & $764(79.2 \%)$ & $143(14.8 \%)$ & $11(1.1 \%)$ & $7(0.7 \%)$ & $40(4.2 \%)$ \\
\hline
\end{tabular}


Table 2. Result of responses from industrial layout

\begin{tabular}{|c|c|c|c|c|c|c|}
\hline \multicolumn{7}{|c|}{ Sub-study area: Industrial layout } \\
\hline Students: 25 & Employed: 53 & \multicolumn{3}{|c|}{ Unemployed: 22} & \multicolumn{2}{|c|}{ Total: 100} \\
\hline $\begin{array}{l}\text { Students who } \\
\text { have not } \\
\text { heard of vet: } 1\end{array}$ & $\begin{array}{l}\text { Employed who } \\
\text { have not heard of } \\
\text { vet: } 0\end{array}$ & \multicolumn{3}{|c|}{$\begin{array}{l}\text { Unemployed who have not heard of } \\
\text { vet: } 2\end{array}$} & \multicolumn{2}{|c|}{ Total: $\mathbf{3}$} \\
\hline \multicolumn{2}{|l|}{ Questions } & $\begin{array}{l}\text { Strongly } \\
\text { agree }\end{array}$ & Agree & $\begin{array}{l}\text { Strongly } \\
\text { disagree }\end{array}$ & Disagree & No idea \\
\hline \multicolumn{2}{|c|}{$\begin{array}{l}\text { A veterinary doctor is a professional } \\
\text { who is licensed to diagnose and treat } \\
\text { animal diseases }\end{array}$} & $77(77.0 \%)$ & $18(18.0 \%)$ & Nil & Nil & $5(5.0 \%)$ \\
\hline \multicolumn{2}{|c|}{$\begin{array}{l}\text { A veterinary doctor is a laboratory } \\
\text { scientist that diagnoses and treats } \\
\text { animal diseases }\end{array}$} & $39(39.0 \%)$ & $45(45.0 \%)$ & $5(5.0 \%)$ & $2(2.0 \%)$ & $9(9.0 \%)$ \\
\hline \multicolumn{2}{|c|}{$\begin{array}{l}\text { A veterinary doctor is a community } \\
\text { leader in the scientific world }\end{array}$} & $45(45.0 \%)$ & $22(22.0 \%)$ & $18(18.0 \%)$ & $5(5.0 \%)$ & $10(10.0)$ \\
\hline \multicolumn{2}{|c|}{$\begin{array}{l}\text { Veterinary doctors have a more } \\
\text { standard training programme on } \\
\text { livestock management, production } \\
\text { and health; compared to animal } \\
\text { scientists }\end{array}$} & $28(28.0 \%)$ & $48(48.0 \%)$ & $5(5.0 \%)$ & $9(9.0 \%)$ & $10(10.0 \%)$ \\
\hline \multicolumn{2}{|c|}{$\begin{array}{l}\text { Nigerian abattoirs are in a bad state } \\
\text { because veterinarians have not been } \\
\text { authorized by law to manage them }\end{array}$} & $32(32.0 \%)$ & $45(45.0 \%)$ & $2(2.0 \%)$ & $6(6.0 \%)$ & $15(15.0 \%)$ \\
\hline \multicolumn{2}{|c|}{$\begin{array}{l}\text { Veterinary medicine and human } \\
\text { medicine are complementary in the } \\
\text { disease control strategy of any nation }\end{array}$} & $61(61.0 \%)$ & $33(33.0 \%)$ & $1(1.0 \%)$ & $1(1.0 \%)$ & $4(4.0 \%)$ \\
\hline \multicolumn{2}{|c|}{$\begin{array}{l}\text { For effective disease diagnoses, } \\
\text { prevention and control, veterinary } \\
\text { teaching hospitals in Nigerian } \\
\text { universities should be equipped and } \\
\text { better funded than it is currently }\end{array}$} & $54(54.0 \%)$ & $34(34.0 \%)$ & $3(3.0 \%)$ & $3(3.0 \%)$ & $6(6.0 \%)$ \\
\hline \multicolumn{2}{|c|}{$\begin{array}{l}\text { Household animal production for } \\
\text { family income generation in Benue } \\
\text { state has not been encouraged by } \\
\text { the government via provision of } \\
\text { essential support facilities to the } \\
\text { farmer }\end{array}$} & $73(73.0 \%)$ & $18(18.0 \%)$ & Nil & $4(4.0 \%)$ & $5(5.0)$ \\
\hline \multicolumn{2}{|c|}{$\begin{array}{l}\text { To reduce farmer-transhumance } \\
\text { nomadic Fulani clash, the Fulani's } \\
\text { should be encouraged to settle and } \\
\text { establish ranches for effective } \\
\text { livestock business in Nigeria }\end{array}$} & $20(20.0 \%)$ & $16(16.0 \%)$ & $16(16.0)$ & $35(35.0 \%)$ & $13(13.0 \%)$ \\
\hline \multicolumn{2}{|c|}{$\begin{array}{l}\text { Nigerian governments should } \\
\text { establish treaties with the } \\
\text { governments of developed countries } \\
\text { to train its veterinarians both locally } \\
\text { and internationally }\end{array}$} & $73(73.0 \%)$ & $21(21.0 \%)$ & Nil & $1(1.0 \%)$ & $5(5.0 \%$ \\
\hline \multicolumn{2}{|c|}{$\begin{array}{l}\text { Nigerian government should } \\
\text { encourage veterinarians to be self } \\
\text { employed after graduation from the } \\
\text { university by providing them an } \\
\text { interest free loan to establish } \\
\text { livestock farms, veterinary clinics or } \\
\text { other professional businesses }\end{array}$} & $94(94.0 \%)$ & $1(1.0 \%)$ & Nil & Nil & $5(5.0 \%)$ \\
\hline
\end{tabular}


Table 3. Result of responses from Wurukum

\begin{tabular}{|c|c|c|c|c|c|}
\hline \multicolumn{6}{|c|}{ Sub-study area: Wurukum } \\
\hline Employed: 45 & \multicolumn{3}{|c|}{ Unemployed: 28} & \multicolumn{2}{|c|}{ Total: 100} \\
\hline Employed who have not heard & \multicolumn{3}{|c|}{ Unemployed who have not heard of vet: 5} & \multicolumn{2}{|c|}{ Total: 5} \\
\hline Questions & Strongly agree & Agree & Strongly disagree & Disagree & No idea \\
\hline $\begin{array}{l}\text { A veterinary doctor is a professional who is licensed to diagnose } \\
\text { and treat animal diseases }\end{array}$ & $80(80.0 \%)$ & $15(15.0 \%)$ & Nil & Nil & $5(5.0 \%)$ \\
\hline $\begin{array}{l}\text { A veterinary doctor is a laboratory scientist that diagnoses and } \\
\text { treats animal diseases }\end{array}$ & $69(69.0 \%)$ & $20(20.0 \%)$ & Nil & $4(4.0 \%)$ & $7(7.0 \%)$ \\
\hline A veterinary doctor is a community leader in the scientific world & $58(58.0 \%)$ & $24(24.0 \%)$ & $2(2.0 \%)$ & $5(5.0 \%)$ & $11(11.0 \%)$ \\
\hline $\begin{array}{l}\text { Veterinary doctors have a more standard training programme on } \\
\text { livestock management, production and health; compared to } \\
\text { animal scientists }\end{array}$ & $55(55.0 \%)$ & $24(24.0 \%)$ & $3(3.0 \%)$ & $5(5.0 \%)$ & $13(13.0 \%)$ \\
\hline $\begin{array}{l}\text { Nigerian abattoirs are in a bad state because veterinarians have } \\
\text { not been authorized by law to manage them }\end{array}$ & $34(34.0 \%)$ & $24(24.0 \%)$ & $7(7.0 \%)$ & $15(15.0 \%)$ & $30(30.0 \%)$ \\
\hline $\begin{array}{l}\text { Veterinary medicine and human medicine are complementary in } \\
\text { the disease control strategy of any nation }\end{array}$ & $68(68.0 \%)$ & $20(20.0 \%)$ & $\mathrm{Nil}$ & $1(1.0 \%)$ & $11(11.0 \%)$ \\
\hline $\begin{array}{l}\text { For effective disease diagnoses, prevention and control, } \\
\text { veterinary teaching hospitals in Nigerian universities should be } \\
\text { equipped and better funded than it is currently }\end{array}$ & $57(57.0 \%)$ & $30(30.0 \%)$ & $1(1.0 \%)$ & $\mathrm{Nil}$ & $12(12.0 \%)$ \\
\hline $\begin{array}{l}\text { Household animal production for family income generation in } \\
\text { Benue state has not been encouraged by the government via } \\
\text { provision of essential support facilities to the farmer }\end{array}$ & $72(72.0 \%)$ & $16(16.0 \%)$ & $2(2.0 \%)$ & $\mathrm{Nil}$ & $10(10.0 \%)$ \\
\hline $\begin{array}{l}\text { To reduce farmer-transhumance nomadic Fulani clash, the } \\
\text { Fulani's should be encouraged to settle and establish ranches for } \\
\text { effective livestock business in Nigeria }\end{array}$ & $23(23.0 \%)$ & $15(15.0 \%)$ & $13(13.0 \%)$ & $37(37.0)$ & $12(12 .-0 \%)$ \\
\hline $\begin{array}{l}\text { Nigerian governments should establish treaties with the } \\
\text { governments of developed countries to train its veterinarians both } \\
\text { locally and internationally }\end{array}$ & $79(79.0 \%)$ & $16(16.0 \%)$ & Nil & Nil & $5(5.0 \%)$ \\
\hline $\begin{array}{l}\text { Nigerian government should encourage veterinarians to be self } \\
\text { employed after graduation from the university by providing them } \\
\text { an interest free loan to establish livestock farms, veterinary clinics } \\
\text { or other professional businesses }\end{array}$ & $87(87.0 \%)$ & $8(8.0 \%)$ & Nil & Nil & $5(5.0 \%)$ \\
\hline
\end{tabular}


Table 4. Result of responses from Benue State University community

\begin{tabular}{|c|c|c|c|c|c|c|}
\hline \multicolumn{7}{|c|}{ Sub-study area: Benue State University } \\
\hline Students: 76 & Employed: 19 & \multirow{2}{*}{\multicolumn{3}{|c|}{$\begin{array}{c}\text { Unemployed: } 5 \\
\text { Unemployed who have not heard of vet: } 3\end{array}$}} & \multirow{2}{*}{\multicolumn{2}{|c|}{$\begin{array}{l}\text { Total: } 100 \\
\text { Total: } \mathbf{3}\end{array}$}} \\
\hline $\begin{array}{l}\text { Students who have not heard } \\
\text { of vet: } 0\end{array}$ & $\begin{array}{l}\text { Employed who have not } \\
\text { heard of vet: } 0\end{array}$ & & & & & \\
\hline \multicolumn{2}{|l|}{ Questions } & Strongly agree & Agree & $\begin{array}{l}\text { Strongly } \\
\text { disagree }\end{array}$ & Disagree & No idea \\
\hline \multicolumn{2}{|c|}{$\begin{array}{l}\text { A veterinary doctor is a professional who is licensed to diagnose } \\
\text { and treat animal diseases }\end{array}$} & $77(77.0 \%)$ & $20(20.0 \%)$ & Nil & Nil & $3(3.0 \%)$ \\
\hline \multicolumn{2}{|c|}{$\begin{array}{l}\text { A veterinary doctor is a laboratory scientist that diagnoses and } \\
\text { treats animal diseases }\end{array}$} & $52(52.0 \%)$ & $32(32.0 \%)$ & $2(2.0 \%)$ & $3(3.0 \%)$ & $11(11.0 \%)$ \\
\hline \multicolumn{2}{|c|}{ A veterinary doctor is a community leader in the scientific world } & $36(36.0 \%)$ & $26(26.0 \%)$ & $7(7.0 \%)$ & $16(16.0 \%)$ & $15(15.0 \%)$ \\
\hline \multicolumn{2}{|c|}{$\begin{array}{l}\text { Veterinary doctors have a more standard training programme on } \\
\text { livestock management, production and health; compared to animal } \\
\text { scientists }\end{array}$} & $33(33.0 \%)$ & $38(38.0 \%)$ & $3(3.0 \%)$ & $4(4.0 \%)$ & $22(22.0 \%)$ \\
\hline \multicolumn{2}{|c|}{$\begin{array}{l}\text { Nigerian abattoirs are in a bad state because veterinarians have } \\
\text { not been authorized by law to manage them }\end{array}$} & $40(40.0 \%)$ & $25(25.0 \%)$ & $2(2.0 \%)$ & $12(12.0 \%)$ & $21(21.0 \%)$ \\
\hline \multicolumn{2}{|c|}{$\begin{array}{l}\text { Veterinary medicine and human medicine are complementary in } \\
\text { the disease control strategy of any nation }\end{array}$} & $46(46.0 \%)$ & $38(38.0 \%)$ & $1(1.0 \%)$ & $4(4.0 \%)$ & $11(11.0 \%)$ \\
\hline \multicolumn{2}{|c|}{$\begin{array}{l}\text { For effective disease diagnoses, prevention and control, veterinary } \\
\text { teaching hospitals in Nigerian universities should be equipped and } \\
\text { better funded than it is currently }\end{array}$} & $55(55.0 \%)$ & $37(37.0 \%)$ & $1(1.0 \%)$ & $1(1.0 \%)$ & $6(6.0 \%)$ \\
\hline \multicolumn{2}{|c|}{$\begin{array}{l}\text { Household animal production for family income generation in } \\
\text { Benue state has not been encouraged by the government via } \\
\text { provision of essential support facilities to the farmer }\end{array}$} & $50(50.0 \%)$ & $31(31.0 \%)$ & $3(3.0 \%)$ & $6(6.0 \%)$ & $10(10.0 \%)$ \\
\hline \multicolumn{2}{|c|}{$\begin{array}{l}\text { To reduce farmer-transhumance nomadic Fulani clash, the Fulani's } \\
\text { should be encouraged to settle and establish ranches for effective } \\
\text { livestock business in Nigeria }\end{array}$} & $43(43.0 \%)$ & $29(29.0 \%)$ & $5(5.0 \%)$ & $15(15.0 \%)$ & $8(8.0 \%)$ \\
\hline \multicolumn{2}{|c|}{$\begin{array}{l}\text { Nigerian governments should establish treaties with the } \\
\text { governments of developed countries to train its veterinarians both } \\
\text { locally and internationally }\end{array}$} & $65(65.0 \%)$ & $28(28.0 \%)$ & $2(2.0 \%)$ & $1(1.0 \%)$ & $4(4.0 \%)$ \\
\hline \multicolumn{2}{|c|}{$\begin{array}{l}\text { Nigerian government should encourage veterinarians to be self } \\
\text { employed after graduation from the university by providing them an } \\
\text { interest free loan to establish livestock farms, veterinary clinics or } \\
\text { other professional businesses }\end{array}$} & $69(69.0 \%)$ & $26(26.0 \%)$ & $2(2.0 \%)$ & Nil & $3(3.0 \%)$ \\
\hline
\end{tabular}




\section{Table 5. Result of responses from University of Agriculture Makurdi community}

\begin{tabular}{|c|c|c|c|c|c|}
\hline \multicolumn{6}{|c|}{ Sub-study area: University of Agriculture Makurdi community } \\
\hline Employed: 23 & \multirow{2}{*}{\multicolumn{3}{|c|}{$\begin{array}{c}\text { Unemployed: } 11 \\
\text { Unemployed who have not heard of vet: } 0\end{array}$}} & \multirow{2}{*}{\multicolumn{2}{|c|}{$\begin{array}{c}\text { Total: } 102 \\
\text { Total: } 1\end{array}$}} \\
\hline $\begin{array}{l}\text { Employed who have not } \\
\text { heard of vet: } 0\end{array}$ & & & & & \\
\hline Questions & Strongly agree & Agree & Strongly disagree & Disagree & No idea \\
\hline $\begin{array}{l}\text { A veterinary doctor is a professional who is licensed to } \\
\text { diagnose and treat animal diseases }\end{array}$ & $72(70.6 \%)$ & $26(25.4 \%)$ & $1(1.0 \%)$ & $2(2.0 \%)$ & $1(1.0 \%)$ \\
\hline $\begin{array}{l}\text { A veterinary doctor is a laboratory scientist that diagnoses and } \\
\text { treats animal diseases }\end{array}$ & $26(25.4 \%)$ & $52(51.0 \%)$ & $15(14.7 \%)$ & $7(6.9 \%)$ & $2(2.0 \%)$ \\
\hline A veterinary doctor is a community leader in the scientific world & $8(7.8 \%)$ & $19(18.6 \%)$ & $30(29.5 \%)$ & $35(34.3 \%)$ & $10(9.8 \%)$ \\
\hline $\begin{array}{l}\text { Veterinary doctors have a more standard training programme } \\
\text { on livestock management, production and health; compared to } \\
\text { animal scientists }\end{array}$ & $29(28.4 \%)$ & $40(39.2 \%)$ & $9(8.8 \%)$ & $17(16.7 \%)$ & $7(6.9 \%)$ \\
\hline $\begin{array}{l}\text { Nigerian abattoirs are in a bad state because veterinarians } \\
\text { have not been authorized by law to manage them }\end{array}$ & $24(23.5 \%)$ & $40(39.2 \%)$ & $6(5.9 \%)$ & $11(10.8 \%)$ & $21(20.6 \%)$ \\
\hline $\begin{array}{l}\text { Veterinary medicine and human medicine are complementary in } \\
\text { the disease control strategy of any nation }\end{array}$ & $45(44.1 \%)$ & $45(44.1 \%)$ & $5(4.9 \%)$ & $3(3.0 \%)$ & $4(3.9 \%)$ \\
\hline $\begin{array}{l}\text { For effective disease diagnoses, prevention and control, } \\
\text { veterinary teaching hospitals in Nigerian universities should be } \\
\text { equipped and better funded than it is currently }\end{array}$ & $62(60.8 \%)$ & $35(34.3 \%)$ & $1(1.0 \%)$ & $1(1.0 \%)$ & $3(2.9 \%)$ \\
\hline $\begin{array}{l}\text { Household animal production for family income generation in } \\
\text { Benue state has not been encouraged by the government via } \\
\text { provision of essential support facilities to the farmer }\end{array}$ & $50(49.0 \%)$ & $39(38.2 \%)$ & Nil & $3(3.0 \%)$ & $10(9.8 \%)$ \\
\hline $\begin{array}{l}\text { To reduce farmer-transhumance nomadic Fulani clash, the } \\
\text { Fulani's should be encouraged to settle and establish ranches } \\
\text { for effective livestock business in Nigeria }\end{array}$ & $48(47.1 \%)$ & $33(32.4 \%)$ & $12(11.8 \%)$ & $5(4.9 \%)$ & $4(3.9 \%)$ \\
\hline $\begin{array}{l}\text { Nigerian governments should establish treaties with the } \\
\text { governments of developed countries to train its veterinarians } \\
\text { both locally and internationally }\end{array}$ & $60(58.8 \%)$ & $35(34.3 \%)$ & $3(3.0 \%)$ & $2(2.0 \%)$ & $2(1.0 \%)$ \\
\hline $\begin{array}{l}\text { Nigerian government should encourage veterinarians to be self } \\
\text { employed after graduation from the university by providing them } \\
\text { an interest free loan to establish livestock farms, veterinary } \\
\text { clinics or other professional businesses }\end{array}$ & $78(76.4 \%)$ & $20(19.6 \%)$ & $1(1.0 \%)$ & $2(2.0 \%)$ & $1(1.0 \%)$ \\
\hline
\end{tabular}


Table 6. Result of responses from Nyiman layout

\begin{tabular}{|c|c|c|c|c|c|}
\hline \multicolumn{6}{|c|}{ Sub-study area: Nyiman layout } \\
\hline Employed: 31 & & Unemploy & & \multirow{2}{*}{\multicolumn{2}{|c|}{$\begin{array}{c}\text { Total: } 92 \\
\text { Total: } 4\end{array}$}} \\
\hline Employed WHO have not heard & \multicolumn{3}{|c|}{$\begin{array}{l}\text { Unemployed: } 22 \\
\text { Unemployed WHO have not heard of vet: } 3\end{array}$} & & \\
\hline Questions & Strongly agree & Agree & Strongly disagree & Disagree & No idea \\
\hline $\begin{array}{l}\text { A veterinary doctor is a professional who is licensed to diagnose } \\
\text { and treat animal diseases }\end{array}$ & $66(71.7 \%)$ & $21(22.8 \%)$ & Nil & Nil & $5(5.4 \%)$ \\
\hline $\begin{array}{l}\text { A veterinary doctor is a laboratory scientist that diagnoses and } \\
\text { treats animal diseases }\end{array}$ & $19(20.7 \%)$ & $42(45.7 \%)$ & $13(14.1 \%)$ & $6(6.5 \%)$ & $12(13.0)$ \\
\hline A veterinary doctor is a community leader in the scientific world & $13(14.1 \%)$ & $34(37.0 \%)$ & $19(20.7 \%)$ & $11(12.0)$ & $15(16.3 \%)$ \\
\hline $\begin{array}{l}\text { Veterinary doctors have a more standard training programme on } \\
\text { livestock management, production and health; compared to animal } \\
\text { scientists }\end{array}$ & $29(31.5)$ & $39(42.4 \%)$ & $7(7.6 \%)$ & $8(8.7 \%)$ & $9(9.8 \%)$ \\
\hline $\begin{array}{l}\text { Nigerian abattoirs are in a bad state because veterinarians have not } \\
\text { been authorized by law to manage them }\end{array}$ & $29(31.5 \%)$ & $32(34.8 \%)$ & $4(4.3 \%)$ & $15(16.3 \%)$ & $12(13.0 \%)$ \\
\hline $\begin{array}{l}\text { Veterinary medicine and human medicine are complementary in the } \\
\text { disease control strategy of any nation }\end{array}$ & $35(38.0 \%)$ & $37(40.0 \%)$ & $5(5.4 \%)$ & $4(4.3 \%)$ & $11(12.0 \%)$ \\
\hline $\begin{array}{l}\text { For effective disease diagnoses, prevention and control, veterinary } \\
\text { teaching hospitals in Nigerian universities should be equipped and } \\
\text { better funded than it is currently }\end{array}$ & $40(43.5 \%)$ & $39(42.4 \%)$ & $1(1.1 \%)$ & $4(4.3 \%)$ & $8(8.7 \%)$ \\
\hline $\begin{array}{l}\text { Household animal production for family income generation in Benue } \\
\text { state has not been encouraged by the government via provision of } \\
\text { essential support facilities to the farmer }\end{array}$ & $29(31.5 \%)$ & $42(45.7 \%)$ & $3(3.2 \%)$ & $9(9.8 \%)$ & $9(9.8 \%)$ \\
\hline $\begin{array}{l}\text { To reduce farmer-transhumance nomadic Fulani clash, the Fulani's } \\
\text { should be encouraged to settle and establish ranches for effective } \\
\text { livestock business in Nigeria }\end{array}$ & $40(43.5 \%)$ & $32(34.8 \%)$ & $7(7.6 \%)$ & $7(7.6 \%)$ & $6(6.5 \%)$ \\
\hline $\begin{array}{l}\text { Nigerian governments should establish treaties with the } \\
\text { governments of developed countries to train its veterinarians both } \\
\text { locally and internationally }\end{array}$ & $47(51.1 \%)$ & $35(38.0 \%)$ & $2(2.2 \%)$ & $3(3.2 \%)$ & $5(5.4 \%)$ \\
\hline $\begin{array}{l}\text { Nigerian government should encourage veterinarians to be self } \\
\text { employed after graduation from the university by providing them an } \\
\text { interest free loan to establish livestock farms, veterinary clinics or } \\
\text { other professional businesses }\end{array}$ & $51(55.4 \%)$ & $29(31.5 \%)$ & $4(4.3 \%)$ & $2(2.2 \%)$ & $6(6.5 \%)$ \\
\hline
\end{tabular}


Table 7. Result of responses from Low Level

\begin{tabular}{|c|c|c|c|c|c|}
\hline \multicolumn{6}{|c|}{ Sub-study area: low level } \\
\hline Employed: 35 & & Unemplo & & \multirow{2}{*}{\multicolumn{2}{|c|}{$\begin{array}{c}\text { Total: } \mathbf{7 1} \\
\text { Total: } 6\end{array}$}} \\
\hline Employed who have not heard & Unem & d who have & d of vet: 4 & & \\
\hline Questions & Strongly agree & Agree & Strongly disagree & Disagree & No idea \\
\hline $\begin{array}{l}\text { A veterinary doctor is a professional who is licensed to diagnose } \\
\text { and treat animal diseases }\end{array}$ & $62(87.3 \%)$ & $3(4.3 \%)$ & Nil & Nil & $6(8.5 \%)$ \\
\hline $\begin{array}{l}\text { A veterinary doctor is a laboratory scientist that diagnoses and } \\
\text { treats animal diseases }\end{array}$ & $50(70.4 \%)$ & $14(19.7 \%)$ & $1(1.4 \%)$ & Nil & $6(5.9 \%)$ \\
\hline A veterinary doctor is a community leader in the scientific world & $40(56.3 \%)$ & $10(14.1 \%)$ & $9(12.7 \%)$ & $1(1.4 \%)$ & $11(15.5 \%)$ \\
\hline $\begin{array}{l}\text { Veterinary doctors have a more standard training programme on } \\
\text { livestock management, production and health; compared to } \\
\text { animal scientists }\end{array}$ & $32(45.1 \%)$ & $9(12.7 \%)$ & $7(9.9 \%)$ & Nil & $23(32.4 \%)$ \\
\hline $\begin{array}{l}\text { Nigerian abattoirs are in a bad state because veterinarians have } \\
\text { not been authorized by law to manage them }\end{array}$ & $29(40.8 \%)$ & $13(18.3 \%)$ & $2(2.8 \%)$ & $7(9.9 \%)$ & $20(28.2 \%)$ \\
\hline $\begin{array}{l}\text { Veterinary medicine and human medicine are complementary in } \\
\text { the disease control strategy of any nation }\end{array}$ & $49(69.0 \%)$ & $12(16.9 \%)$ & $\mathrm{Nil}$ & Nil & $10(14.1 \%)$ \\
\hline $\begin{array}{l}\text { For effective disease diagnoses, prevention and control, veterinary } \\
\text { teaching hospitals in Nigerian universities should be equipped and } \\
\text { better funded than it is currently }\end{array}$ & $44(62.0 \%)$ & $15(21.1 \%)$ & $2(2.8 \%)$ & $\mathrm{Nil}$ & $10(14.1 \%)$ \\
\hline $\begin{array}{l}\text { Household animal production for family income generation in } \\
\text { Benue state has not been encouraged by the government via } \\
\text { provision of essential support facilities to the farmer }\end{array}$ & $49(69.0 \%)$ & $5(7.0 \%)$ & $\mathrm{Nil}$ & Nil & $17(23.9 \%)$ \\
\hline $\begin{array}{l}\text { To reduce farmer-transhumance nomadic Fulani clash, the } \\
\text { Fulani's should be encouraged to settle and establish ranches for } \\
\text { effective livestock business in Nigeria }\end{array}$ & $27(38.0 \%)$ & $3(4.2 \%)$ & $17(24.0 \%)$ & $14(19.7 \%)$ & $10(14.1 \%)$ \\
\hline $\begin{array}{l}\text { Nigerian governments should establish treaties with the } \\
\text { governments of developed countries to train its veterinarians both } \\
\text { locally and internationally }\end{array}$ & $57(80.3 \%)$ & $8(11.3 \%)$ & $\mathrm{Nil}$ & Nil & $6(8.5 \%)$ \\
\hline $\begin{array}{l}\text { Nigerian government should encourage veterinarians to be self } \\
\text { employed after graduation from the university by providing them an } \\
\text { interest free loan to establish livestock farms, veterinary clinics or } \\
\text { other professional businesses }\end{array}$ & $64(90.0 \%)$ & $1(1.4 \%)$ & Nil & Nil & $6(8.5 \%)$ \\
\hline
\end{tabular}


Table 8. Result of responses from Judges Quarters

\begin{tabular}{|c|c|c|c|c|c|}
\hline \multicolumn{6}{|c|}{ Sub-study area: Judges Quarters } \\
\hline Students: 23 & \multicolumn{3}{|c|}{ Unemployed: 21} & \multirow{2}{*}{\multicolumn{2}{|c|}{$\begin{array}{c}\text { Total: } 100 \\
\text { Total: } 3\end{array}$}} \\
\hline Employed who have not heard & Unem & who have $n$ & of vet: 2 & & \\
\hline Questions & Strongly agree & Agree & $\begin{array}{l}\text { Strongly } \\
\text { disagree }\end{array}$ & Disagree & No idea \\
\hline $\begin{array}{l}\text { A veterinary doctor is a professional who is licensed to diagnose } \\
\text { and treat animal diseases }\end{array}$ & $73(73.0 \%)$ & $22(22.0 \%)$ & Nil & Nil & $5(5.0 \%)$ \\
\hline $\begin{array}{l}\text { A veterinary doctor is a laboratory scientist that diagnoses and } \\
\text { treats animal diseases }\end{array}$ & $39(39.0 \%)$ & $40(40.0 \%)$ & $7(7.0 \%)$ & $6(6.0 \%)$ & $8(8.0 \%)$ \\
\hline A veterinary doctor is a community leader in the scientific world & $29(29.0 \%)$ & $21(21.0 \%)$ & $23(23.0 \%)$ & $15(15.0 \%)$ & $12(12.0 \%)$ \\
\hline $\begin{array}{l}\text { Veterinary doctors have a more standard training programme on } \\
\text { livestock management, production and health; compared to } \\
\text { animal scientists }\end{array}$ & $25(25.0 \%)$ & $31(31.0 \%)$ & $13(13.0 \%)$ & $12(12.0 \%)$ & $19(19.0 \%)$ \\
\hline $\begin{array}{l}\text { Nigerian abattoirs are in a bad state because veterinarians have } \\
\text { not been authorized by law to manage them }\end{array}$ & $29(29.0 \%)$ & $29(29.0 \%)$ & $10(10.0 \%)$ & $12(12.0 \%)$ & $20(20.0 \%)$ \\
\hline $\begin{array}{l}\text { Veterinary medicine and human medicine are complementary in } \\
\text { the disease control strategy of any nation }\end{array}$ & $42(42.0 \%)$ & $34(34.0 \%)$ & $1(1.0 \%)$ & Nil & $23(23.0 \%)$ \\
\hline $\begin{array}{l}\text { For effective disease diagnoses, prevention and control, } \\
\text { veterinary teaching hospitals in Nigerian universities should be } \\
\text { equipped and better funded than it is currently }\end{array}$ & $61(61.0 \%)$ & $31(31.0 \%)$ & $2(2.0 \%)$ & Nil & $6(6.0 \%)$ \\
\hline $\begin{array}{l}\text { Household animal production for family income generation in } \\
\text { Benue state has not been encouraged by the government via } \\
\text { provision of essential support facilities to the farmer }\end{array}$ & $62(62.0 \%)$ & $21(21.0 \%)$ & $2(2.0 \%)$ & $\mathrm{Nil}$ & $15(15.0 \%)$ \\
\hline $\begin{array}{l}\text { To reduce farmer-transhumance nomadic Fulani clash, the } \\
\text { Fulani's should be encouraged to settle and establish ranches for } \\
\text { effective livestock business in Nigeria }\end{array}$ & $43(43.0 \%)$ & $20(20.0 \%)$ & $\begin{array}{l}15 \\
(15.0 \%)\end{array}$ & $15(15.0 \%)$ & $7(7.0 \%)$ \\
\hline $\begin{array}{l}\text { Nigerian governments should establish treaties with the } \\
\text { governments of developed countries to train its veterinarians both } \\
\text { locally and internationally }\end{array}$ & $75(75.0 \%)$ & $20(20.0 \%)$ & $\mathrm{Nil}$ & Nil & $5(5.0 \%)$ \\
\hline $\begin{array}{l}\text { Nigerian government should encourage veterinarians to be self } \\
\text { employed after graduation from the university by providing them } \\
\text { an interest free loan to establish livestock farms, veterinary clinics } \\
\text { or other professional businesses }\end{array}$ & $88(88.0 \%)$ & $7(7.0 \%)$ & $\mathrm{Nil}$ & Nil & $5(5.0 \%)$ \\
\hline
\end{tabular}


Table 9. Result of responses from North-Bank

\begin{tabular}{|c|c|c|c|c|c|}
\hline \multicolumn{6}{|c|}{ Sub-study area: North-Bank } \\
\hline Employed: 29 & & Unemploy & & \multirow{2}{*}{\multicolumn{2}{|c|}{$\begin{array}{c}\text { Total: } 100 \\
\text { Total: } 1\end{array}$}} \\
\hline Employed who have not heard & \multicolumn{3}{|c|}{ Unemployed who have not heard of vet: 1} & & \\
\hline Questions & Strongly agree & Agree & Strongly disagree & Disagree & No idea \\
\hline $\begin{array}{l}\text { A veterinary doctor is a professional who is licensed to diagnose } \\
\text { and treat animal diseases }\end{array}$ & $84(84.0 \%)$ & $11(11.0 \%)$ & Nil & Nil & $5(5.0 \%)$ \\
\hline $\begin{array}{l}\text { A veterinary doctor is a laboratory scientist that diagnoses and } \\
\text { treats animal diseases }\end{array}$ & $37(37.0 \%)$ & $34(34.0 \%)$ & $7(7.0 \%)$ & $13(13.0 \%)$ & $9(9.0 \%)$ \\
\hline A veterinary doctor is a community leader in the scientific world & $9(9.0 \%)$ & $30(30.0 \%)$ & $17(17.0 \%)$ & $24(24.0 \%)$ & $20(20.0 \%)$ \\
\hline $\begin{array}{l}\text { Veterinary doctors have a more standard training programme on } \\
\text { livestock management, production and health; compared to animal } \\
\text { scientists }\end{array}$ & $31(31.0 \%)$ & $35(35.0 \%)$ & $8(8.0 \%)$ & $11(11.0 \%)$ & $15(15.0 \%)$ \\
\hline $\begin{array}{l}\text { Nigerian abattoirs are in a bad state because veterinarians have } \\
\text { not been authorized by law to manage them }\end{array}$ & $29(29.0 \%)$ & $36(36.0 \%)$ & $7(7.0 \%)$ & $8(8.0 \%)$ & $20(20.0 \%)$ \\
\hline $\begin{array}{l}\text { Veterinary medicine and human medicine are complementary in } \\
\text { the disease control strategy of any nation }\end{array}$ & $40(40.0 \%)$ & $50(50.0 \%)$ & $1(1.0 \%)$ & $2(2.0 \%)$ & $7(7.0 \%)$ \\
\hline $\begin{array}{l}\text { For effective disease diagnoses, prevention and control, veterinary } \\
\text { teaching hospitals in Nigerian universities should be equipped and } \\
\text { better funded than it is currently }\end{array}$ & $71(71.0 \%)$ & $20(20.0 \%)$ & $1(1.0 \%)$ & $\mathrm{Nil}$ & $8(8.0 \%)$ \\
\hline $\begin{array}{l}\text { Household animal production for family income generation in } \\
\text { Benue state has not been encouraged by the government via } \\
\text { provision of essential support facilities to the farmer }\end{array}$ & $48(48.0 \%)$ & $35(35.0 \%)$ & Nil & $22.0 \%)$ & $15(15.0 \%)$ \\
\hline $\begin{array}{l}\text { To reduce farmer-transhumance nomadic Fulani clash, the Fulani's } \\
\text { should be encouraged to settle and establish ranches for effective } \\
\text { livestock business in Nigeria }\end{array}$ & $41(41.0 \%)$ & $36(36.0 \%)$ & $5(5.0 \%)$ & $10(10.0 \%)$ & $8(8.0 \%)$ \\
\hline $\begin{array}{l}\text { Nigerian governments should establish treaties with the } \\
\text { governments of developed countries to train its veterinarians both } \\
\text { locally and internationally }\end{array}$ & $6161.0 \%)$ & $31(31.0 \%)$ & $3(3.0 \%)$ & Nil & $5(5.0 \%)$ \\
\hline $\begin{array}{l}\text { Nigerian government should encourage veterinarians to be self } \\
\text { employed after graduation from the university by providing them an } \\
\text { interest free loan to establish livestock farms, veterinary clinics or } \\
\text { other professional businesses }\end{array}$ & $77(77.0 \%)$ & $15(15.0 \%)$ & $2(2.0 \%)$ & Nil & $6(6.0 \%)$ \\
\hline
\end{tabular}




\section{Table 10. Result of responses from High Level}

\begin{tabular}{|c|c|c|c|c|c|c|}
\hline \multicolumn{7}{|c|}{ Sub-study area: high level } \\
\hline Students: 56 & Employed: 29 & \multicolumn{3}{|c|}{ Unemployed: 15} & \multicolumn{2}{|c|}{ Total: 100} \\
\hline $\begin{array}{l}\text { Students who have not heard } \\
\text { of vet: } 0\end{array}$ & $\begin{array}{l}\text { Employed who have not } \\
\text { heard of vet: } 0\end{array}$ & \multicolumn{3}{|c|}{ Unemployed who have not heard of vet: 0} & \multicolumn{2}{|c|}{ Total: 0} \\
\hline Questions & & Strongly agree & Agree & $\begin{array}{l}\text { Strongly } \\
\text { disagree }\end{array}$ & Disagree & No idea \\
\hline $\begin{array}{l}\text { A veterinary doctor is a professio } \\
\text { and treat animal diseases }\end{array}$ & al who is licensed to diagnose & $75(75.0 \%)$ & $23(23.0 \%)$ & Nil & $1(1.0 \%)$ & $1(1.0 \%)$ \\
\hline $\begin{array}{l}\text { A veterinary doctor is a laborato } \\
\text { treats animal diseases }\end{array}$ & scientist that diagnoses and & $34(34.0 \%)$ & $48(48.0 \%)$ & $2(2.0 \%)$ & $9(9.0 \%)$ & $7(7.0 \%)$ \\
\hline A veterinary doctor is a communi & $y$ leader in the scientific world & $10(10.0 \%)$ & $26(26.0 \%)$ & $14(14.0 \%)$ & $37(37.0 \%)$ & $13(13.0 \%)$ \\
\hline $\begin{array}{l}\text { Veterinary doctors have a more } \\
\text { livestock management, productio } \\
\text { animal scientists }\end{array}$ & $\begin{array}{l}\text { andard training programme on } \\
\text { and health; compared to }\end{array}$ & $39(39.0 \%)$ & $43(43.0 \%)$ & $2(2.0 \%)$ & $10(10.0 \%)$ & $6(6.0 \%)$ \\
\hline $\begin{array}{l}\text { Nigerian abattoirs are in a bad st } \\
\text { not been authorized by law to ma }\end{array}$ & $\begin{array}{l}\text { te because veterinarians have } \\
\text { nage them }\end{array}$ & $35(35.0 \%)$ & $41(41.0 \%)$ & $6(6.0 \%)$ & $6(6.0 \%)$ & $12(12.0 \%)$ \\
\hline $\begin{array}{l}\text { Veterinary medicine and human } \\
\text { the disease control strategy of an }\end{array}$ & $\begin{array}{l}\text { edicine are complementary in } \\
\text { yation }\end{array}$ & $34(34.0 \%)$ & $45(45.0 \%)$ & $2(2.0 \%)$ & $5(5.0 \%)$ & $14(14.0 \%)$ \\
\hline $\begin{array}{l}\text { For effective disease diagnoses, } \\
\text { veterinary teaching hospitals in } \\
\text { equipped and better funded than }\end{array}$ & $\begin{array}{l}\text { revention and control, } \\
\text { gerian universities should be } \\
t \text { is currently }\end{array}$ & $59(59.0 \%)$ & $36(36.0 \%)$ & $1(1.0 \%)$ & Nil & $4(4.0 \%)$ \\
\hline $\begin{array}{l}\text { Household animal production for } \\
\text { Benue state has not been encou } \\
\text { provision of essential support fac }\end{array}$ & $\begin{array}{l}\text { amily income generation in } \\
\text { aged by the government via } \\
\text { ities to the farmer }\end{array}$ & $40(40.0 \%)$ & $45(45.0 \%)$ & $2(2.0 \%)$ & $3(3.0 \%)$ & $10(10.0 \%)$ \\
\hline $\begin{array}{l}\text { To reduce farmer-transhumance } \\
\text { Fulani's should be encouraged to } \\
\text { for effective livestock business in }\end{array}$ & $\begin{array}{l}\text { lomadic Fulani clash, the } \\
\text { settle and establish ranches } \\
\text { Nigeria }\end{array}$ & $43(43.0 \%)$ & $44(44.0 \%)$ & $5(5.0 \%)$ & $3(3.0 \%)$ & $5(5.0 \%)$ \\
\hline $\begin{array}{l}\text { Nigerian governments should est } \\
\text { governments of developed count } \\
\text { both locally and internationally }\end{array}$ & $\begin{array}{l}\text { blish treaties with the } \\
\text { ies to train its veterinarians }\end{array}$ & $58(58.0 \%)$ & $37(37.0 \%)$ & $2(2.0 \%)$ & $1(1.0 \%)$ & $2(2.0 \%)$ \\
\hline $\begin{array}{l}\text { Nigerian government should enc } \\
\text { employed after graduation from } t \\
\text { an interest free loan to establish } \\
\text { clinics or other professional busir }\end{array}$ & $\begin{array}{l}\text { urage veterinarians to be self } \\
\text { e university by providing them } \\
\text { vestock farms, veterinary } \\
\text { esses }\end{array}$ & $71(71.0 \%)$ & $24(24.0 \%)$ & $2(2.0 \%)$ & $3(3.0 \%)$ & Nil \\
\hline
\end{tabular}


Table 11. Result of responses from new GRA

\begin{tabular}{|c|c|c|c|c|c|c|}
\hline \multicolumn{7}{|c|}{ Sub-study area: new GRA } \\
\hline Students: 39 & Employed: 44 & & Unemploy & & \multirow{2}{*}{\multicolumn{2}{|c|}{$\begin{array}{l}\text { Total: } 100 \\
\text { Total: } \mathbf{3}\end{array}$}} \\
\hline Students who have not heard & Employed who have not & \multicolumn{3}{|c|}{ Unemployed who have not heard of vet: 3} & & \\
\hline \multicolumn{2}{|l|}{ Questions } & Strongly agree & Agree & Strongly disagree & Disagree & No idea \\
\hline \multicolumn{2}{|c|}{$\begin{array}{l}\text { A veterinary doctor is a professional who is licensed to diagnose } \\
\text { and treat animal diseases }\end{array}$} & $75(75.0 \%)$ & $22(22.0 \%)$ & Nil & Nil & $3(3.0 \%)$ \\
\hline \multicolumn{2}{|c|}{$\begin{array}{l}\text { A veterinary doctor is a laboratory scientist that diagnoses and } \\
\text { treats animal diseases }\end{array}$} & $47(47.0 \%)$ & $42(42.0 \%)$ & Nil & $6(6.0 \%)$ & $5(5.0 \%)$ \\
\hline \multicolumn{2}{|c|}{ A veterinary doctor is a community leader in the scientific world } & $34(34.0 \%)$ & $15(15.0 \%)$ & $17(17.0 \%)$ & $17(17.0 \%)$ & $17(17.0 \%)$ \\
\hline \multicolumn{2}{|c|}{$\begin{array}{l}\text { Veterinary doctors have a more standard training programme on } \\
\text { livestock management, production and health; compared to } \\
\text { animal scientists }\end{array}$} & $42(42.0 \%)$ & $26(26.0 \%)$ & $8(8.0 \%)$ & $6(6.0 \%)$ & $18(18.0 \%)$ \\
\hline \multicolumn{2}{|c|}{$\begin{array}{l}\text { Nigerian abattoirs are in a bad state because veterinarians have } \\
\text { not been authorized by law to manage them }\end{array}$} & $22(22.0 \%)$ & $24(24.0 \%)$ & $9(9.0 \%)$ & $14(14.0 \%)$ & $31(31.0 \%)$ \\
\hline \multicolumn{2}{|c|}{$\begin{array}{l}\text { Veterinary medicine and human medicine are complementary in } \\
\text { the disease control strategy of any nation }\end{array}$} & $65(65.0 \%)$ & $24(24.0 \%)$ & Nil & $2(2.0 \%)$ & $9(9.0 \%)$ \\
\hline \multicolumn{2}{|c|}{$\begin{array}{l}\text { For effective disease diagnoses, prevention and control, veterinary } \\
\text { teaching hospitals in Nigerian universities should be equipped and } \\
\text { better funded than it is currently }\end{array}$} & $72(72.0 \%)$ & $21(21.0 \%)$ & Nil & Nil & $7(7.0 \%)$ \\
\hline \multicolumn{2}{|c|}{$\begin{array}{l}\text { Household animal production for family income generation in } \\
\text { Benue state has not been encouraged by the government via } \\
\text { provision of essential support facilities to the farmer }\end{array}$} & $64(64.0 \%)$ & $22(22.0 \%)$ & Nil & $2(2.0 \%)$ & $12(12.0 \%)$ \\
\hline \multicolumn{2}{|c|}{$\begin{array}{l}\text { To reduce farmer-transhumance nomadic Fulani clash, the } \\
\text { Fulani's should be encouraged to settle and establish ranches for } \\
\text { effective livestock business in Nigeria }\end{array}$} & $29(29.0 \%)$ & $29(29.0 \%)$ & $15(15.0 \%)$ & $22(22.0 \%)$ & $5(5.0 \%)$ \\
\hline \multicolumn{2}{|c|}{$\begin{array}{l}\text { Nigerian governments should establish treaties with the } \\
\text { governments of developed countries to train its veterinarians both } \\
\text { locally and internationally }\end{array}$} & 75 (75.0\%) & $20(20.0 \%)$ & $1(1.0 \%)$ & $1(1.0 \%)$ & $3(3.0 \%)$ \\
\hline \multicolumn{2}{|c|}{$\begin{array}{l}\text { Nigerian government should encourage veterinarians to be self } \\
\text { employed after graduation from the university by providing them } \\
\text { an interest free loan to establish livestock farms, veterinary clinics } \\
\text { or other professional businesses }\end{array}$} & $85(85.0 \%)$ & $12(12.0 \%)$ & Nil & Nil & $3(3.0 \%)$ \\
\hline
\end{tabular}


The present study inferred that the unemployment status of Nigerian veterinarians is a serious issue that most responsible governments will rather exploit positively. With such veterinarians empowered to be self-reliant in their professional calling, without depending on government jobs, they will employ other unemployed, skilled and unskilled workers. Majority of respondents $(P<0.05)$ strongly agreed that unemployed veterinarians should be supported by the Nigerian government to acquire non-interest (interest-free) loan facilities to establish livestock farms, veterinary clinics or other forms of agro businesses to not just employ themselves, but also the unskilled and skilled workforce in the industry. This will further mop up unemployment in the national workforce to a reasonable level.

\section{CONCLUSION}

It was concluded that the veterinarian is an indispensable professional, whose training must be exploited by government in transforming society. The Nigerian government should be encouraged to involve veterinary doctors in all disease prevention and control strategy plans in the country. The authors suggest that Veterinary Teaching Hospitals in Nigerian universities should be well equipped to achieve the disease eradication goal of the federal government of Nigeria predicated on millennium development goals (MDGs) of the United Nations (UN). Traditional rulers and government have a role to play in the peaceful coexistence between farmers and transhumance Fulani pastoralists of rural Nigeria. There should be efforts to settle the Fulanis with an encouragement to establish ranches for more effective livestock production for meat, milk supply etc in Nigeria and for foreign exchange earnings.

\section{ACKNOWLEDGEMENT}

The authors of this manuscript are grateful to Mrs. Vivian Adamu for the secretarial assistance.

\section{COMPETING INTERESTS}

Authors have declared that no competing interests exist.

\section{REFERENCES}

1. MedicineNet.com: Definition of Veterinary Medicine.www.medicinenet.com/script/mai $\mathrm{n} /$ mobileart.asp?articlekey=20572. 2014.

2. Veterinary Surgeons of Nigeria Act. 1969.

3. VCN: College of Veterinary Surgeons Nigeria (CVSN) Prospectus.

Available:www.vcng.org/node/122. 2006.

4. Adejoro SO. The role of veterinary doctors in economic development of Oyo state, Nigeria. An invited paper by Nigeria Veterinary Medical Association (NVMA), Oyo state, Jogor Centre held on $28^{\text {th }}$ August, 2013.

5. Babalobi OO. Professional Issues for the Nigerian Veterinarian in the Twenty First Century. Nig. Vet. J. 2005;26:1-7.

6. City population.de: Makurdi local government area population.

Available:www.citypopulation.de/php/nigeri a-admin.php?adm2id=NGA007013m.2013.

7. Chartfield C. A course in applied statistics. United Kingdom and Hall, London. 1983.

8. Adewunmi $\mathrm{R}$, Ebotmanchang BD. Undergraduates view of the veterinary profession: A study of Ahmadu Bello University Zaria, Nigeria. Nig. Vet. J. 2004;25:1-8.

9. Lusigi WJ. Combatting Desertification and Rehabilitating Degraded Production Systems in Northern Kenya. IPAL, UNESCO, Nairobi. 1981;141.

10. Gibbs EPJ. The evolution of one medicine: A decade of progress and challenges for the future. Vet. Rec. 2014;174:85-91.

(C) 2019 Ode et al.; This is an Open Access article distributed under the terms of the Creative Commons Attribution License (http://creativecommons.org/licenses/by/4.0), which permits unrestricted use, distribution, and reproduction in any medium, provided the original work is properly cited.

Peer-review history:

The peer review history for this paper can be accessed here: http://www.sdiarticle3.com/review-history/22151 